\title{
Insulin Secretion Stimulated by Allogeneic Lymphocytes in an Inbred Strain of Mice
}

\author{
J. B. García, M. C. Venturino, E. Alvarez, L. Fabiano de Bruno, M. Braun, O. H. Pivetta, and J. C. Basabe \\ Fundación Laboratorios de Investigaciones Pediátricas, Hospital General de Niños "Dr. Pedro de Elizalde," Centro de Estudios \\ Farmacológicos y de Principios Maturales, and Instituto Nacional de Genética Médica, Buenos Aires, Argentina
}

\begin{abstract}
Effects of intraperitoneal injection of allogeneic lymphocytes on insulin secretion were studied in incubated pancreas slices from BALB/c mice. Injection of allogeneic lymphocytes from C57BL/ 6J (H2b) mice increased insulin secretion, both in basal and 11mM glucose-stimulated conditions. This effect was only present when at least $5 \times 10^{6}$ or $1 \times 10^{6}$ cells were injected (in basal and stimulated conditions, respectively). Glucose-induced insulin secretion (3.3-27.5 mM) was significantly increased in pancreata from mice injected with allogeneic lymphocytes. No effect was observed when glucose was not included in the incubation medium. Intraperitoneal injection of Dextran 70 produced no change in glucose-elicited insulin secretion. There were no differences in glucagon and somatostatin (SRIF) secretion obtained from pancreas of mice injected with allogeneic or syngeneic lymphocytes. Injection of allogeneic cells increases insulin secretion (basal and both phases of $11 \mathrm{mM}$ glucose-stimulated secretion). Puromycin significantly inhibited the second phase of insulin secretion. These results suggest that: (a) Injection of allogeneic lymphocytes raises both basal and glucose-stimulated insulin secretion. (b) This effect seems to be connected with the major histocompatibility complex, and to be related to the number of allogeneic cells injected. (c) Injection of allogeneic lymphocytes seems to sensitize the beta cell response to glucose stimulus. (d) Neither glucagon nor SRIF secretion are altered by alloantigen injection. (e) The stimulatory effect of allogeneic lymphocytes is related, at least in part, to insulin synthesis.
\end{abstract}

\section{Introduction}

Interaction between the endocrine and immune system is complex and the study of potentially critical factors needs multidisciplinary analysis.

Numerous findings support the existence of regulatory circuits between the immune and endocrine systems. Antigen injection into mice induces a rapid increase in gonadotropins blood levels, the pharmacological suppression of which results in a blockade of antibody synthesis and specific tolerance (1).

Resting $\mathrm{T}$ lymphocytes have no insulin receptors, but they develop them de novo after nonspecific mitogen stimulation by Concanavalin A $(2,3)$. Insulin provided to receptor-bearing lymphocytes increases intermediary metabolism above mitogen-

Address reprint requests to Dr. Basabe, Fundacion FLIP, Montes de Oca 40 (1270), Buenos Aires, Argentina.

Received for publication 11 September 1984 and in revised form 31 October 1985.

J. Clin. Invest.

(c) The American Society for Clinical Investigation, Inc.

0021-9738/86/05/1453/07 \$1.00

Volume 77, April 1986, 1453-1459 stimulated levels (4). Furthermore, insulin as well as other ligands, which increase intracytoplasmatic cyclic guanosine monophosphate, augment lymphocyte-mediated cytotoxicity (5). These factors strongly suggest a physiological role for insulin in immunoregulation.

In a previous set of experiments, we found that sheep red blood cell injection into inbred mice caused an increase in insulin secretion from incubated pancreas slices (authors' unpublished data).

The following study was designed to investigate the response of mice endocrine pancreas to alloantigen injection.

\section{Methods}

\section{Animal model}

We used 6-9-wk-old male and female, fed inbred BALB/c, C57BL/KsJ, and $\mathrm{C} 57 \mathrm{BL} / 6 \mathrm{~J}$ mice provided by the Instituto Nacional de Genética Médica (Buenos Aires).

\section{Preparation of cell suspensions}

Cell suspensions were prepared by two methods: $(a)$ The tissue (spleen) was submitted to a soft mechanical disruption in cold saline solution for homogenization; it was washed three times, and concentration was adjusted to $50 \times 10^{6}$ cells per milliliter; $(b)$ In other experiments spleen lymphocytes were purified by centrifugation in a Ficoll-Hypaque gradient. No differences were observed between the results obtained by both methods. (Insulin secretion, $\mathrm{ng} / 100 \mathrm{mg}$ wet tissue per $20 \mathrm{~min}$ of incubation: Basal, syngeneic lymphocytes, method $(a) 4.1 \pm 0.8$ vs. method (b) $4.0 \pm 0.7$; allogeneic lymphocytes, (a) $13.2 \pm 0.6$ vs. (b) $12.5 \pm 0.5$; stimulated, syngeneic lymphocytes, (a) $62 \pm 3.5$ vs. (b) $61.3 \pm 5$.2; allogeneic lymphocytes, (a) $133.2 \pm 10.4$ vs. (b) $114.4 \pm 4$.6). Therefore, we used the first method described in all further experiments.

\section{Experimental model}

Antigen injection. $10^{7}$ spleen cells from BALB/c (H2d), C57BL/KsJ or $\mathrm{C} 57 \mathrm{BL} / 6 \mathrm{~J}(\mathrm{H} 2 \mathrm{~b})$ mice resuspended in a volume of $0.2 \mathrm{ml}$ were injected intraperitoneally into BALB/c mice. The animals were killed 30,60 , 120 , and $300 \mathrm{~min}$ after injection and each mouse's pancreas was removed in order to be incubated as specified in "Incubation technique," below.

In a separate set of experiments, Dextran T70 (Pharmacia Fine Chemicals, Piscataway, NJ), a conventional soluble antigen, at a concentration of 50 or $500 \mu \mathrm{g}$ diluted in $0.2 \mathrm{ml}$ saline, was injected intraperitoneally into BALB/c mice. The animals were killed $90 \mathrm{~min}$ after injection and each animal's pancreas was removed to be incubated as discussed in "Dynamics of insulin secretion," below.

Bidirectional lymphocytes culture (BALB/c vs. $C 3 H$ ). Purified lymphocytes suspensions were prepared from spleen cells by Ficoll-Hypaque gradient. After washing, they were resuspended at a concentration of $10^{7}$ cells/ml in RPMI 1640 with $5 \%$ fetal calf serum and antibiotics, and cultured in plastic mignon tubes at $37^{\circ} \mathrm{C}$ for different time periods (Table I). Replicate cultures were pooled, centrifugated at $1,500 \mathrm{rpm}$ for 10 min, and the supernatants were used without further manipulations.

Dynamics of insulin secretion. $10^{7}$ spleen cells from BALB/c or from $\mathrm{C} 57 \mathrm{BL} / 6 \mathrm{~J}$ mice were injected intraperitoneally into $\mathrm{BALB} / \mathrm{c}$ mice. The mice were killed $90 \mathrm{~min}$ after injection and pancreata were removed for perifusion. 
Table I. Insulin Secretion Stimulated by Supernatant of Bidirectional Lymphocytes Culture

\begin{tabular}{|c|c|c|c|c|}
\hline \multicolumn{2}{|c|}{ Basal glucose, $3.3 \mathrm{mM}$} & \multirow{2}{*}{$\begin{array}{l}\text { Culture } \\
\text { time }\end{array}$} & \multicolumn{2}{|c|}{ Stimulated glucose, $11 \mathrm{mM}$} \\
\hline Experimental & Control & & Experimental & Control \\
\hline & & $h$ & & \\
\hline $5.5 \pm 0.5$ & $5.6 \pm 0.8$ & 0.5 & $48.3 \pm 5.7$ & $39.1 \pm 1.8$ \\
\hline $5.4 \pm 0.5$ & $5.1 \pm 0.3$ & 1 & $57.6 \pm 5.0$ & $54.0 \pm 2.2$ \\
\hline $7.0 \pm 0.4$ & $5.5 \pm 0.4$ & 3 & $96.2 \pm 2.8^{*}$ & $54.3 \pm 4.5$ \\
\hline $5.7 \pm 0.6$ & $4.6 \pm 0.4$ & 6 & $88.7 \pm 5.8^{*}$ & $53.6 \pm 1.8$ \\
\hline $4.5 \pm 0.3$ & $4.5 \pm 0.3$ & 12 & $54.4 \pm 7.2$ & $45.9 \pm 3.6$ \\
\hline
\end{tabular}

Insulin secretion (ng/100 mg w.t./20 min, $\overline{\mathrm{X}} \pm \mathrm{SEM}$ ) produced by pancreas from BALB/c mice incubated in presence of supernatant of bidirectional lymphocyte culture (BALB/c vs. $\mathrm{C} 3 \mathrm{H}$ ) diluted $1 / 10$ (experimental). Control pancreata were incubated in the presence of supernatant of BALB/c or $\mathrm{C} 3 \mathrm{H}$ lymphocytes culture.

* $P<0.001$; note differences between experimental and control in stimulated 11-mM glucose.

Incubation technique. The incubation technique described by Martin and Bambers (6) was employed. After killing the animals by decapitation, we excised the splenic portion of each mouse's pancreas, and removed the adipose tissue, lymphatic vessels, and nodules. Slices of pancreas were transferred into flasks containing $2 \mathrm{ml}$ of incubation buffer and were preincubated for $15 \mathrm{~min}$ at $4^{\circ} \mathrm{C}$ in an ice-cold water bath under constant gassing with a mixture of $95 \% \mathrm{O}_{2}$ and $5 \% \mathrm{CO}_{2}$. The slices were transferred into new flasks with fresh buffer and incubated for $15 \mathrm{~min}$ in a Dubnoff incubator (recuperation period). Then the slices were transferred into flasks with fresh buffer and incubated for $20 \mathrm{~min}$ at $37^{\circ} \mathrm{C}$ (basal period). The pancreatic tissue was finally transferred into a fourth group of flasks and incubated for $20 \mathrm{~min}$ at $37^{\circ} \mathrm{C}$ in the presence of 11 $\mathrm{mM}$ glucose as stimulus for insulin secretion (stimulated period).

The incubation medium was Krebs-Ringer bicarbonate (pH, 7.387.42) supplemented with $60 \mathrm{mg} \%$ glucose, $1 \mathrm{~g} \%$ bovine serum albumin, and $1,000 \mathrm{KIU} / \mathrm{ml}$ protease inhibitor Trasylol.

Perifusion technique. The technique described by Burr et al. (7) was used. The perifusion medium and the procedure to obtain the slices of pancreas were similar to those described above. Glucose, $11 \mathrm{mM}$, used as stimulus for insulin secretion, was added to the perifusion medium at $3 \mathrm{~min}$. The proteolytic effect on the hormonal secretion was avoided by using Trasylol in the buffer and by collecting the samples on $0.25 \mathrm{M}$ EDTA in tubes at $4^{\circ} \mathrm{C}$, which were immediately frozen at $-20^{\circ} \mathrm{C}$.

\section{Hormonal dosage}

Insulin. Insulin was determined by the method of Herbert et al. (8) modified by Cresto et al. (9). The pork monoiodine insulin of high specific activity was labeled with ${ }^{125} \mathrm{I}$, separated by means of a starch preparative gel chromatography, and purified by passage through a Sephadex G-100 column. The rat standard insulin was obtained from Novo Research Laboratories (Denmark). The anti-insulin antibody proved to be sufficiently "nonspecific" to displace the labeled insulin b both the rat standard and our experimental insulin. This method allowed determination within $0.4-32 \mathrm{ng} / \mathrm{ml}$ range.

Glucagon. Glucagon was determined by the Serono Biodata Glucagon polyethylene glycol (PEG). Kit, Hypolab S.A. (Switzerland), batches 10727 and 10810 . With minor modifications in the antiserum dilution, this method allowed determination within a $15-1,000 \mathrm{ng} / \mathrm{ml}$ range.

Somatostatin (SRIF).' Somatostatin was assayed with the technique

1. Abbreviations used in this paper: SRIF, somatostatin; Tyr, tyrosinyl. of Arimura et al. (10). Antisera I650 against SRIF, SRIF standard, and tyrosinyl (Tyr $\left.{ }^{1}\right)$-SRIF were obtained from UCB Bioproducts, Peptide Department (Bruxelles, Belgium). The sensitivity of the assay, calculated as the least amount of SRIF causing significant displacements of ${ }^{125} \mathrm{I}-$ Tyr'-SRIF from antibody $(P<0.005)$, was $1.5-2.0 \mathrm{pg} /$ tube; serial dilutions were parallel to the standard curve. Neither insulin, glucagon, pancreatic polypeptide, nor gastrin used in the standard curve displaced ${ }^{125}{ }^{2}$-Tyr'-SRIF from the antiserum under radioimmunoassay conditions.

\section{Statistics}

One-way analysis of variance or Student's $t$ test were used (11).

\section{Results}

Intraperitoneal injection of C57BL/6J (H2b) lymphocytes into BALB/c (H2d) mice significantly increased insulin secretion, both in basal (3.3 mM glucose) and stimulated ( $11 \mathrm{mM}$ glucose) conditions. This rise was observed when the mice were sacrificed 30,60 , and $120 \mathrm{~min}$ after injection, but not when they were sacrificed $300 \mathrm{~min}$ after injection (Fig. 1). The same effect was obtained when allogeneic lymphocytes were injected intravenously (insulin as $\mathrm{ng} / 100 \mathrm{mg}$ wet tissue per $20 \mathrm{~min}$ incubation; (a) basal conditions: allogeneic injected mice, $8.2 \pm 0.5$ vs. syngeneic injected mice, $4.0 \pm 0.4, P<0.001 ;(b)$ stimulated conditions: allogeneic injected mice, $106 \pm 8.7$ vs. syngeneic injected mice, 49.8 $\pm 8.8, P<0.01 ; n=5$ in all groups). Furthermore, a significant increase in insulin secretion induced by intraperitoneal injection of allogeneic lymphocytes, was only observed when at least $5 \times 10^{6}$ cells (basal conditions) or $1 \times 10^{6}$ cells (glucosestimulated conditions) were injected (Fig. 2).

It can also be seen in Fig. 1, that when BALB/c (H2d) mice were injected with lymphocytes from C57BL/KsJ (H2d) mice, there was no change in the amount of insulin secreted.

Table I shows that the supernatant of bidirectional lymphocytes cultures, obtained at 3 and $6 \mathrm{~h}$, enhances glucose-stimulated insulin secretion from BALB/c incubated mice pancreas.

No differences in glycemic levels between animals intraperitoneally injected with allogeneic or syngeneic lymphocytes were observed (glycemic levels expressed as $\mathrm{mg} / \mathrm{dl}, 90 \mathrm{~min}$ after injection: (a) allogeneic lymphocyte-injected mice: $113 \pm 8$ vs. (b) syngeneic lymphocyte-injected mice, $137 \pm 11, P$ NS).

In vivo peripheral insulin levels of allogeneic lymphocyte intraperitoneally injected mice $(3.9 \pm 0.2 \mathrm{ng} / \mathrm{ml})$ showed no differences when compared with syngeneic lymphocyte-injected animals $(3.6 \pm 0.2 \mathrm{ng} / \mathrm{ml})$.

Table II shows that Dextran 70, injected intraperitoneally, 50 or $500 \mu \mathrm{g}$ in $0.2 \mathrm{ml}$ saline, did not modify either the basal or the glucose-stimulated insulin secretion.

The amount of insulin secretion produced by different glucose concentrations obtained from the pancreas of animals injected with syngeneic or allogeneic lymphocytes, can be seen in Table III. In both groups insulin levels were significantly higher than control values ( $3.3 \mathrm{mM}$ glucose), and the levels attained were higher as glucose concentration increased (but only until $16.6 \mathrm{mM}$ glucose, since there was a plateau in the response to 16.6 and $27.5 \mathrm{mM}$ glucose in both groups). If the results obtained in Table III are expressed in terms of a dose response relation between glucose concentration in the incubation medium and insulin response levels, the injection of allogeneic lymphocytes shifts the response to the left, even when glucose concentrations within the plateau (16.6 and $27.5 \mathrm{mM}$ ) are used. 


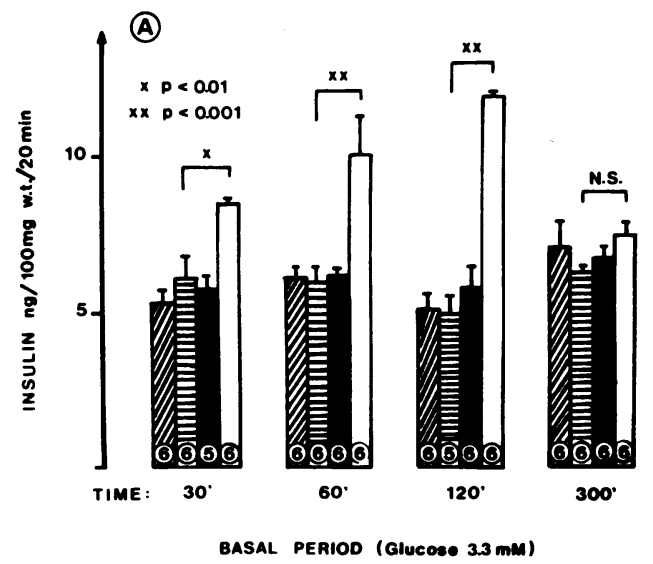

Table III also shows that the stimulatory effect of alloantigen injection on insulin secretion was not observed in a medium containing $0 \mathrm{mM}$ glucose.

In our experimental conditions allogeneic lymphocyte injection did not modify glucagon secretion, either in basal or in both phases of $5.5 \mathrm{mM}$ glucose $/ 20 \mathrm{mM}$ arginine-stimulated conditions, as can be observed in Table IV (the point at which the maximal value was attained, was considered representative of the first phase of glucagon release, generally at $5 \mathrm{~min}$ of perifusion; and the value occurring at $\mathbf{4 0} \mathrm{min}$ as representative of the second phase).

Somatostatin secretion pattern, both in basal and glucosestimulated conditions, was not altered by the injection of allogeneic cells (Fig. 3).

Fig. 4 shows insulin secretion patterns stimulated with 11 $\mathrm{mM}$ glucose from perifused slices of pancreas of BALB/c mice injected with allogeneic or syngeneic lymphocytes. Injection of allogeneic lymphocytes induced a pattern of basal and stimulated hormone response, significantly higher than control. (Area under the curve in nanograms of secreted insulin per $100 \mathrm{mg}$ of pancreatic tissue, $\overline{\mathrm{X}} \pm \mathrm{SEM}$; pancreas of mice injected with allogeneic lymphocytes vs. pancreas of mice injected with syngeneic lymphocytes. Basal: minutes $1-3,9.8 \pm 0.5$ vs. $5.2 \pm 0.5, P<0.001$.
First phase: minutes $4-8,42 \pm 0.5$ vs. $25 \pm 0.6, P<0.001$. Second phase: minutes $10-40,447 \pm 13$ vs. $325 \pm 16, P<0.001$ ).

In some groups Puromycin, $80 \mu \mathrm{g} / \mathrm{ml}$, was added to the perifusion medium. In all cases this drug was perifused during 30 min immediately before sample collection, and was then perifused for $\mathbf{4 0 ~} \mathrm{min}$ in each experiment. At the concentration used, Puromycin inhibits $95-99 \%$ of $\left[{ }^{14} \mathrm{C}\right]$ valine incorporation into pancreatic proteins.

The second phase of insulin secretion induced by $11 \mathrm{mM}$ glucose in pancreas from mice injected with allogeneic cells, is clearly inhibited by Puromycin (Fig. 5). (Area under the curve in nanograms of secreted insulin per $100 \mathrm{mg}$ of pancreatic tissue, $\overline{\mathrm{X}} \pm \mathrm{SEM}$; without Puromycin, $448 \pm 12$; with Puromycin, $307 \pm 3$, $P<0.001)$. In this case the amount and pattern of insulin secretion were similar to those obtained when pancreata from mice injected with syngeneic lymphocytes were stimulated with 11 $\mathrm{mM}$ glucose in absence of Puromycin. (Area under the curve, $325 \pm 13 \mathrm{ng} / 100 \mathrm{mg}$ pancreatic tissue).

At $5 \mathrm{mM}$ concentration, glucose caused only one phase insulin secretion. Injection of alloantigenic cells increased this first phase of insulin secretion and clearly induced a biphasic secretion pattern with a remarkable potentiation of the second phase (Fig. 6; $P<0.001$ from 10 to $40 \mathrm{~min}$. Area under the curve in nano-

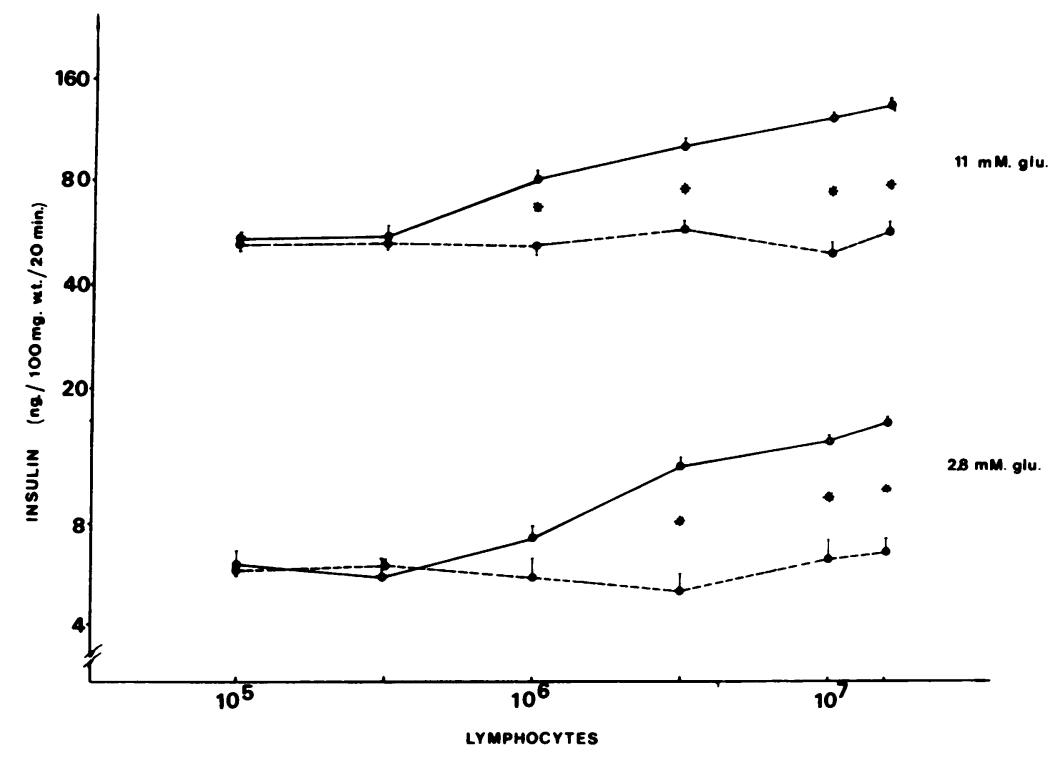

Figure 2. Insulin secretion induced by $11 \mathrm{mM}(t o p)$ or $5.5 \mathrm{mM}$ glucose (bottom) from pancreatic slices belonging to BALB/c mice injected $90 \mathrm{~min}$ before the experiment in presence of different concentrations of allogeneic $(0)$ or syngeneic $(\bullet)$ lymphocytes $(\overline{\mathrm{X}} \pm \mathrm{SEM}$, $n=6$ in each point; $P<0.001)$. 
Table II. Dextran 70 Injection and Insulin Secretion

\begin{tabular}{lll}
\hline & Insulin secretion & \\
\cline { 2 - 3 } Injection & Basal period & Stimulated period \\
\hline & $n g / 100 \mathrm{mg}$ w.t. $/ 20 \mathrm{~min}$ & $n g / 100 \mathrm{mg} \mathrm{w.t.} / 20 \mathrm{~min}$ \\
& & \\
Dextran $50 \mu \mathrm{g}$ & $5.2 \pm 0.5$ & $51.1 \pm 4.8$ \\
Dextran $500 \mu \mathrm{g}$ & $4.5 \pm 0.4$ & $59.3 \pm 6.9$ \\
Saline & $5.3 \pm 0.2$ & $58.6 \pm 6.0$ \\
\hline
\end{tabular}

Effect of intraperitoneal Dextran 70 injection on the basal and $11-\mathrm{mM}$ glucose-induced insulin secretion from incubated pancreas of inbred BALB/c mice ( $n=5$ in each group). w.t., wet tissue.

grams of secreted insulin per $100 \mathrm{mg}$ of pancreatic tissue, $\overline{\mathrm{X}} \pm \mathrm{SEM}$; pancreas of mice injected with syngeneic lymphocytes, $59 \pm 3$; injected with allogeneic lymphocytes, 177 \pm 4 ). Puromycin significantly inhibits the second phase of insulin secretion $(P$ $<0.001$ ) from 20 to 40 min perifusion. However, the "residual" second phase pattern was still significantly higher than the one obtained from pancreata of mice injected with syngeneic cells (areas under the curve, $147 \pm 7.0$ and $59 \pm 2.7 \mathrm{ng} / 100 \mathrm{mg}$ pancreatic tissue, respectively).

\section{Discussion}

Our findings show that endocrine pancreas can respond to antigenic stimulation with an increase in insulin secretion. This rise has already been observed after $30 \mathrm{~min}$ of antigenic intraperitoneal injection. It remains high even after $2 \mathrm{~h}$, but disappears after $5 \mathrm{~h}$. This hormonal response to antigenic stimulation does not seem to be exclusive of pancreas, since Pierpaoli and Maestroni $(1,12,13)$ found an increase in follicle-stimulating hormone and luteinizing hormone plasmatic levels, $2 \mathrm{~h}$ after allogeneic injection. This shows a response of the hypothalamo-hypophyseal axis to an immune aggression.

Our results related to hormonal response to antigen stimulation were characterized by the following findings: $(a)$ When
Table III. Insulin Secretion Induced by Different Glucose Concentration

\begin{tabular}{ccc}
\hline & \multicolumn{2}{l}{ Insulin secretion } \\
\cline { 2 - 3 } Glucose & $\begin{array}{l}\text { Allogeneic lymphocyte } \\
\text { injection }\end{array}$ & $\begin{array}{l}\text { Syngeneic lymphocyte } \\
\text { injection }\end{array}$ \\
\hline$m M$ & $n g / 100 m g$ w.t. $/ 20 \mathrm{~min}$ & $n g / 100 \mathrm{mg}$ w.t. $/ 20 \mathrm{~min}$ \\
0 & $8.32 \pm 1.08$ & $6.76 \pm 0.56$ \\
3.3 & $14.04 \pm 0.64$ & $6.36 \pm 0.66$ \\
5.5 & $82.64 \pm 4.12$ & $41.84 \pm 3.80$ \\
11 & $105.84 \pm 1.72$ & $43.68 \pm 8.68$ \\
14.4 & $122.36 \pm 2.13$ & $50.04 \pm 3.28$ \\
16.6 & $138.92 \pm 4.44$ & $99.60 \pm 6.44$ \\
27.5 & $141.96 \pm 3.04$ & $101.56 \pm 4.16$ \\
\hline
\end{tabular}

Insulin secretion induced by different glucose concentrations from incubated pancreas slices of BALB/c mice sacrificed $90 \mathrm{~min}$ after syngeneic or allogeneic lymphocyte injection (mean \pm SEM; $n=6$ in each group). w.t., wet tissue.

BALB/c mice were injected with allogeneic lymphocytes from $\mathrm{C} 57 \mathrm{BL} / \mathrm{KsJ}$ mice (which have the same $\mathrm{H} 2$ complex as the receptor but in a different genetic background), our experimental model showed no increase in insulin secretion. This suggests that the increase could be related to the major histocompatibility complex. (b) The stimulatory effect of alloantigen on insulin secretion was related to the number of lymphocytes injected. (c) Injection of a conventional soluble antigen, such as Dextran $\mathrm{T} 70$, did not produce any change in the insulin secretion stimulated by glucose. $(d)$ Injection of allogeneic cells did not induce any increase in the insulin release in absence of glucose in the incubation medium. $(e)$ The response that depicts the interrelation between different glucose concentrations and insulin secretion was shifted to the left due to the injection of allogeneic lymphocytes. This could indicate that alloantigen sensitized the beta cell to glucose stimulation.

The fact that allogeneic lymphocyte injected mice did not produce any effect on peripheral insulin levels is surprising. However, consider that in determined conditions, insulin stim-

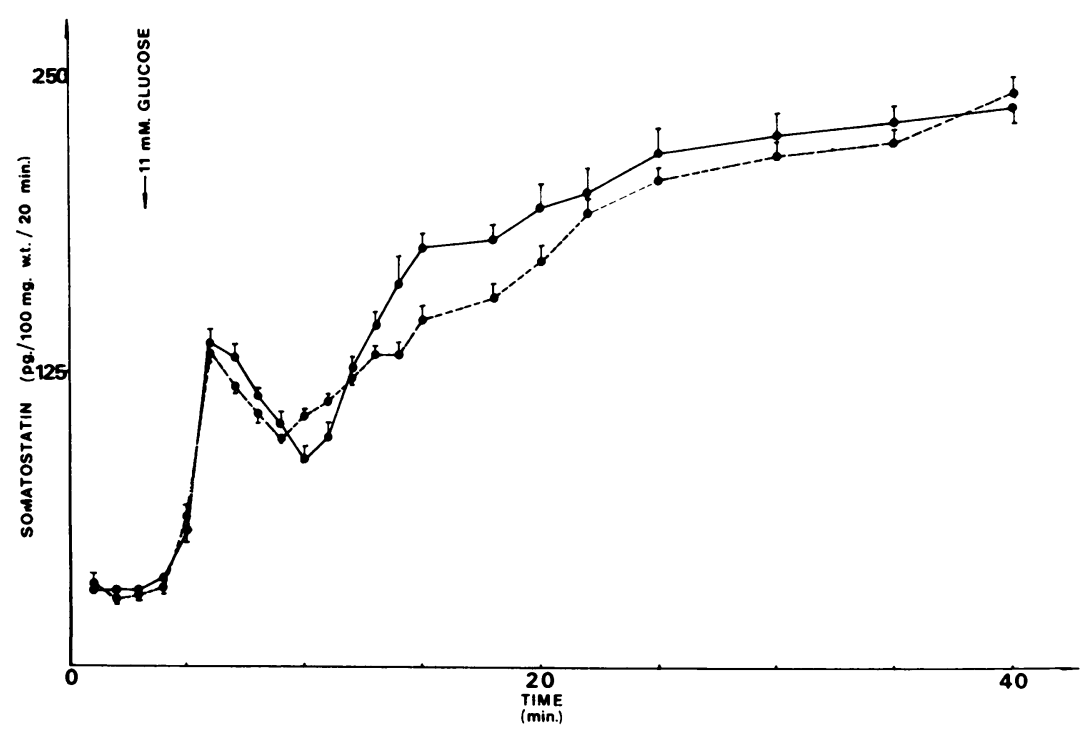

Figure 3. Somatostatin secretion pattern induced by $11 \mathrm{mM}$ glucose from perifused pancreas slices, belonging to BALB/c mice injected 90 min before with allogeneic $(--\bullet--)$ or syngeneic $(-\bullet-)$ lymphocytes $(\overline{\mathrm{X}} \pm \mathrm{SEM}, n=5)$. 


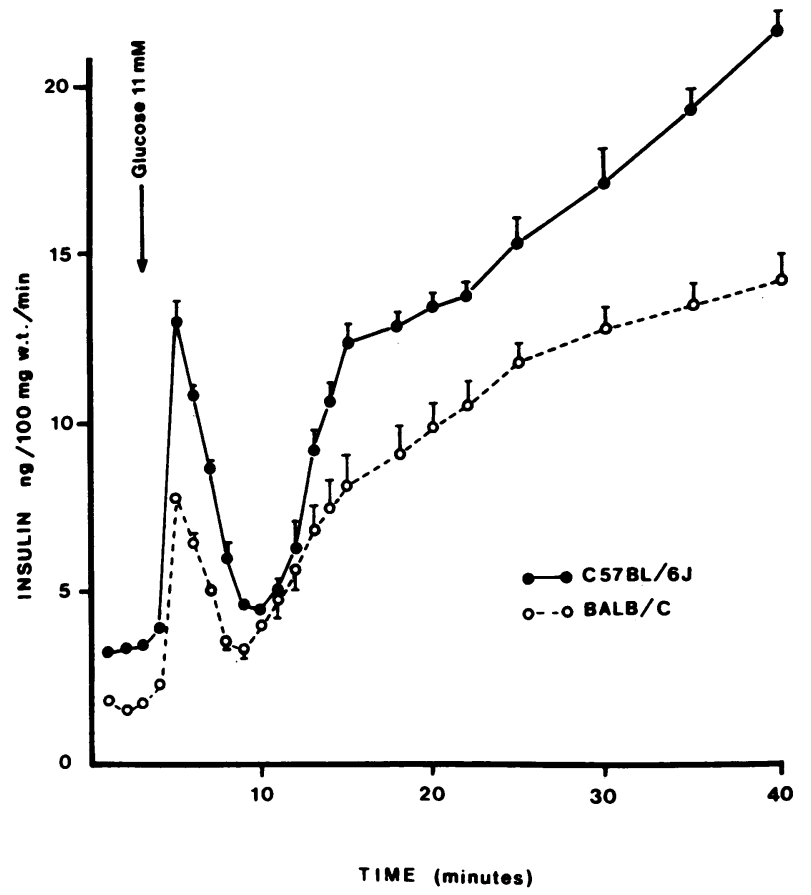

Figure 4. Insulin secretion pattern, stimulated by $11 \mathrm{mM}$ glucose, from perifused pancreas slices belonging to $\mathrm{BALB} / \mathrm{c}$ mice injected 90 min before with allogeneic (C57BL/6J) or syngeneic (BALB/c) lymphocytes $(\overline{\mathrm{X}} \pm \mathrm{SEM}, n=5)$.

ulus can increment portal hormonal levels with little or no change in peripheral insulin concentration $(14,15)$. In our experimental arrangement, peripheral insulin levels were slightly altered but not enough $(P N S)$ to induce any appreciable change on glycemic concentration.

Reports on the immunohistochemistry and electron microscopy of the endocrine pancreas disclosed connections among $\alpha, \beta$, and $\delta$ cells (16). On the basis of this and other reports, the existence of interregulation among insulin, glucagon, and SRIF has been postulated (16-18). This part of the study was devised keeping in mind the fundamental role of the insulin-glucagon
Table IV. Effect of Stimulated Allogeneic and Syngeneic Cells Injection on Glucagon Secretion

\begin{tabular}{|c|c|c|c|c|c|c|}
\hline & \multicolumn{2}{|c|}{ Basal, minute 1} & \multicolumn{2}{|c|}{$\begin{array}{l}\text { First phase, } \\
\text { minute } 5\end{array}$} & \multicolumn{2}{|c|}{$\begin{array}{l}\text { Second phase, } \\
\text { minute } 40\end{array}$} \\
\hline & Allog. & Sing. & Allog. & Sing. & Allog. & Sing. \\
\hline Mean & 163 & 160 & 1,355 & 1,322 & 1,267 & 1,137 \\
\hline SEM & 7 & 14 & 69 & 82 & 39 & 57 \\
\hline
\end{tabular}

Glucagon, $\mathrm{pg} / \mathrm{min}$ per $100 \mathrm{mg}$ wet tissue.

Glucagon secretion induced by $20 / 5.5 \mathrm{mM}$ arginine/glucose from perifused pancreas slices of BALB/c mice injected 90 min before with allogeneic (Allog.) or syngeneic (Sing.) cells (mean \pm SEM; $n=5$ ). Area under the curve: (minutes 3 to $8, \mathrm{pg} / 100 \mathrm{mg}$ w.t.) allogeneic lymphocytes $4,719 \pm 272$ vs. syngeneic lymphocytes, $5,304 \pm 353 ; P$, NS.

balance in metabolic control and the fact that SRIF regulates the secretion of both hormones. In our experimental set, injection of allogeneic lymphocytes did not modify either glucagon or SRIF secretion. This suggests that the stimulatory effect of alloantigen injection acts only on pancreatic data cell secretion.

Constant pancreas stimulus with $11 \mathrm{mM}$ glucose produces a biphasic insulin secretion pattern. The first phase represents the exocytosis of granules formed and aligned in the system of microtubules and microfilaments of the beta cell. The second phase, which is slower and more prolonged, is the result of the release of both accumulated granules and granules with insulin synthetized de novo (19). Stimulation with allogeneic lymphocytes produced an increase in both insulin secretion phases. This seems to indicate that stimulus acts on both the fast and the slow insulin releasing pools. The second phase of glucose-induced insulin secretion can be partially inhibited $(20-30 \%)$ by protein synthesis inhibitors. For this reason it has been postulated that this provisionary phase is related to precursor synthesis (19-21).

Since injection of allogeneic lymphocytes sensitized the second phase of glucose-induced insulin secretion, the question that arises is whether this effect might be related to insulin synthesis or not. As can be seen in Figs. 5 and 6, Puromycin added to the perifusion medium significantly inhibited the second phase of the glucose-stimulated insulin secretion. Although indirectly, this

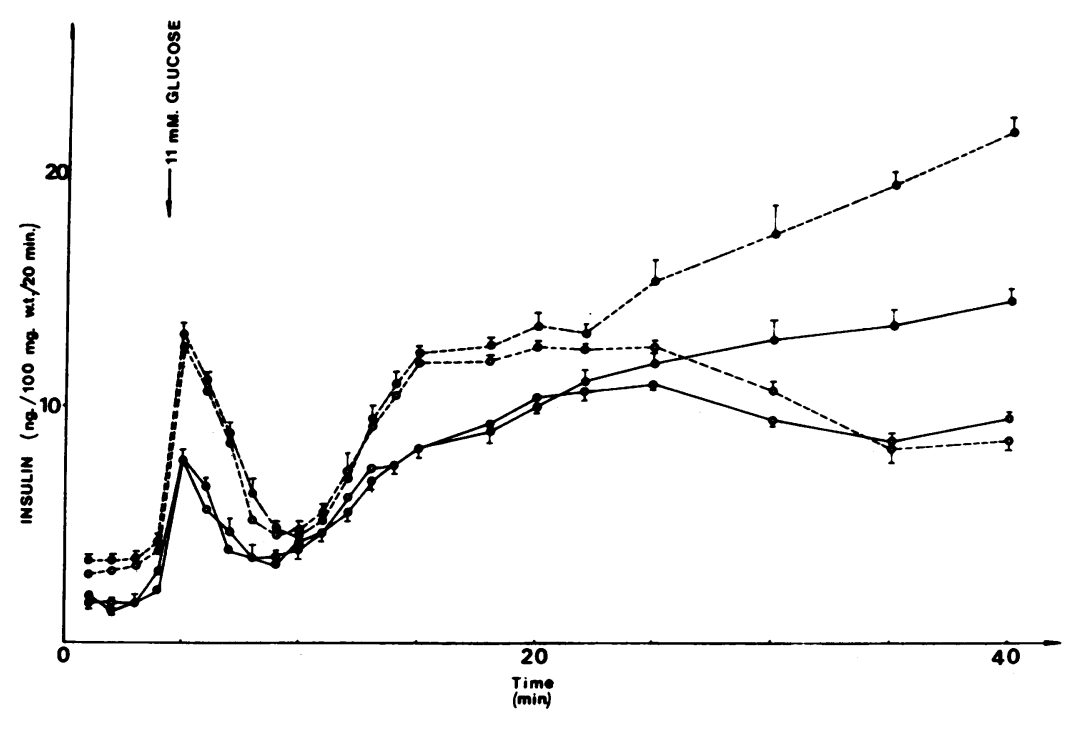

Figure 5. Effect of Puromycin (open circles) on insulin secretion induced by $11 \mathrm{mM}$ glucose from perifused pancreas of mice injected $90 \mathrm{~min}$ before with allogeneic (dotted lines) or with syngeneic (full lines) lymphocytes ( $n=5$ in each group). 


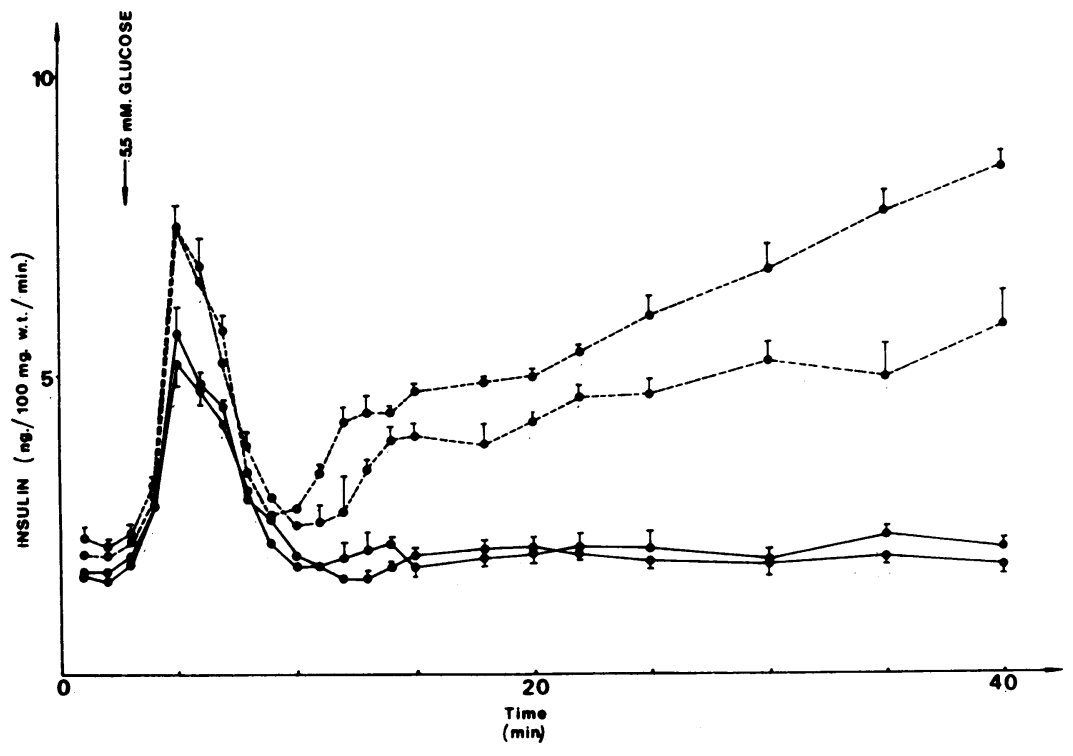

Figure 6. Effect of Puromycin (solid circles) on the insulin secretion induced by $5.5 \mathrm{mM}$ glucose, from perifused pancreas of mice injected $90 \mathrm{~min}$ before with allogeneic (dotted lines) or syngeneic (full lines) lymphocytes ( $n=5$ in each group). showed that the increased sensitivity of the beta cell to glucose induced by allogeneic lymphocytes was related, at least in part, to insulin synthesis.

Glucose at a 5.5-mM concentration caused only one phase insulin secretion. Alloantigen injection, in turn, modified not only the amount but also the pattern of $5.5 \mathrm{mM}$ glucose-induced hormone secretion, substituting a monophasic by a biphasic profile. Incidentally, the change in the insulin secretion pattern caused by the injection of allogeneic lymphocytes, where 5.5 $\mathrm{mM}$ glucose is used as stimulus, was similar to that elicited by glibenclamide, sodium salicylate, or theophylline, all substances with previously reported stimulatory effects on cyclic AMP pancreatic levels (22-24). Although any comment or tentative explanation would be, at present, only speculative, these results could suggest that the increase in beta cell sensitivity to glucose caused by alloantigen injection might be mediated, at least in part, by an effect on cyclic AMP levels.

Insulin secretion by the pancreatic beta cell is regulated in both an immediate (nutrients, neurotransmitters, hormones) and a chronic (ontogenic, endocrine, and nutritional factors) fashion; that is to say, there is a multifactorial regulation for a single process of secretion $(25,26)$. Our results suggest that the immune system should be considered among the insulin secretion regulatory factors. Up to now we do not know the characteristics of this hormonal response to antigenic stimulation. It may be that the immune interaction produces the release of some lymphokine or interleukin capable of stimulating the beta cell. Although the data obtained with the supernatants of bidirectional lymphocytes cultures seem to support a direct effect on the pancreas, they do not rule out that allogeneic lymphocytes might also induce the synthesis or release of nonspecific factor(s) from nonlymphoid tissues that increase insulin secretion.

Regardless of whether these speculations prove correct, our study supplies new data that support the existence of an interrelation between insulin and the immune system.

\section{Acknowledgments}

We wish to thank Miss P. I. Castellani and Mrs. M. M. de Cornet for excellent technical assistance. We are indebted to Dr. R. Gutman from the Endocrinology Unit of Italian Hospital for the antiinsulin serum, and to Bayer Argentina for the supply of Trasylol.

This work was supported in part by grants $8458 / 80$ from the Consejo Nacionel de Investigaciones Cientificas y Técnicas and 10235/82 from Subsecretaria de Ciencia y Técnica. This paper was also supported in part by the Latin American Insulin Grant (Nordisk, Denmark) and by Fundación Alberto J. Röemmers.

\section{References}

1. Pierpaoli, W., and G. J. M. Maestroni. 1977. Pharmacological control of the immune response by blockade of the early hormonal changes following antigen injection. Cell Immunol. 31:355-363.

2. Helderman, J. H., and T. B. Strom. 1977. Emergence of insulin receptors upon alloimmune $\mathrm{T}$ cells in the rat. J. Clin. Invest. 59:338344.

3. Gozes, Y., J. Caruso, and T. B. Strom. 1981. The absence of cryptic insulin receptors on resting $T$ lymphocytes. Diabetes. 30:314316.

4. Helderman, J. H., and L. Edwards. 1981. Role of insulin in the intermediary metabolism of activated thymic-derived lymphocyte. J. Clin. Invest. 67:1636-1642.

5. Strom, T. B., R. A. Bear, and C. B. Carpenter. 1975. Insulininduced augmentation of lymphocyte mediated citotoxicity. Science (Wash. DC). 187:1206-1208.

6. Martin, J. M., and G. Bambers. 1965. Insulin secretion in glucosamine induced hyperglycemia in rats. Am. J. Physiol. 209:797-803.

7. Burr, I. M., L. Balant, W. Stauffacher, and A. E. Renold. 1971. Adrenergic modifications of glucose induced biphasic insulin release from perifused rat pancreas. Eur. J. Clin. Invest. 1:216-224.

8. Herbert, V., K. Lau, C. W. Gottlieb, and S. J. Bleicher. 1965. Coated charcoal immunoassay of insulin. J. Clin. Endocrinol. Metab. 25:1375-1384.

9. Cresto, J. C., I. Dujovne, P. J. Castellani, E. A. Mitta, S. F. de Majo, and V. G. Foglia. 1972. Insulin radioimmunoassay by the charcoal dextran technique. Diabetologia. 8:292-295.

10. Arimura, A., H. Sato, D. Coy, and A. Schally. 1975. Radioimmunoassay of GH-release inhibiting hormone. Proc. Soc. Exp. Biol. Med. 148:784-789.

11. Rattcliffe, J. T. 1969. Elements of mathematical statistics. Oxford University Press, London. 120-132.

12. Pierpaoli, W., and G. J. Maestroni. 1978. Pharmacological control of the hormonally modulated immune response. II. Blockade of antibody production by a combination of drugs acting on neuroendocrine function. 
Its prevention by gonadotrophins and corticotrophin. Immunol. 34:419430.

13. Pierpaoli, W., and G. J. Maestroni. 1978. Pharmacological control of the hormonally modulated immune response. III. Prolongation of allogeneic skin graft rejection and prevention of runt disease by a combination of drugs acting on neuroendocrine functions. J. Immunol. 120: 1600-1603.

14. Porta, D., Jr., L. Girardier, J. Seydoux, Y. Kanasawa, and J. Pasternak. 1973. Neural regulation of insulin secretion in the dog. $J$. Clin. Invest. 52:210-214.

15. Chieri, R., J. M. S. Farina, J. Halperin, and J. C. Basabe. 1975. Effect of cephalic glucose infusion on insulin secretion. Diabetologia. 11:1-6.

16. Orci, L., and R. H. Unger. 1975. Functional subdivision of islets of Langerhans and possible role of D-cells. Lancet ii:1243-1244.

17. Itoh, H., L. Mandarino, and L. Gerich. 1980. Antisomatostatin gamma globulin augments secretion of both insulin and glucagon in vitro. Diabetes. 29:693-696.

18. Basabe, J. C., O. H. Pivetta, L. Fabiano de Bruno, J. C. Cresto, and N. Aparicio. 1983. A temporal study of somatostatin secretion and its inhibitory effect in genetically diabetic mice (C57BL/KsJ-db/db). Endocrinology 113:1927-1934.
19. Lacy, P. E. 1970. Beta cell secretion. From the stand point of a patholobiologist. The Banting Memorial Lecture 1970. Diabetes. 19: 895-905.

20. Curry, D. L., L. Bennett, and G. M. Grodsky. 1968. Dynamic of insulin secretion by the perifused rat pancreas. Endocrinology. 83: 572-584.

21. Basabe, J. C., N. López, J. Viktora, and F. Wolff. 1970. Studies on insulin secretion in the perifused rat pancreas: effect of diazoxide and AO25. Diabetes. 19:271-281.

22. Kuo, W. H., D. Hodgkins, and F. Kuo. 1973. Adenylate cyclase in islets of Langerhans. J. Biol. Chem. 248:2705-2711.

23. Burr, I., L. Balant, W. Stauffacher, and A. E. Renold. 1970. Perifusion of rat pancreatic tissue in vitro: substrate modification of theophylline-induced biphasic insulin release. J. Clin. Invest. 11:2097-2105.

24. Arata, M., L. Karabatas, M. E. Fernández, J. C. Cresto, E. Astolfi, and J. C. Basabe. 1983. Effect of salicylate poisoning on insulin secretion. Studies on its mechanism of action. Acta Diab. Latinoamer. 20:241249.

25. Malaisse, W. J. 1973. Insulin secretion: multifactorial regulation for a single process of release. Diabetologia. 9:167-173.

26. Sutter, Ch. J. 1982. Régulation hormonale de la sécrétion de l'insuline. J. Physiol. (Paris) 78:119-130. 